\title{
Interaction of Skutterudites with Contact Materials: A Metallurgical Analysis
}

\author{
Andriy Grytsiv ${ }^{1,2,3} \cdot$ Gerda Rogl $^{1,2,3} \cdot$ Ernst Bauer $^{2,3} \cdot$ Peter Rogl $^{1,3}$
}

Submitted: 7 February 2020/in revised form: 4 March 2020/Published online: 10 April 2020

(C) The Author(s) 2020

\begin{abstract}
More than hundred diffusion couples between p- and n-type skutterudites and various materials were prepared and interaction zones were investigated after heat treatment at $600{ }^{\circ} \mathrm{C}$ for $1100 \mathrm{~h}$. The constitution of reaction/diffusion zones was discussed in terms of: (a) atom site preference in the skutterudite lattice, (b) phase equilibria in multicomponent systems and (c) particularities of the crystal structure of intermediate phases. It could be shown that phase composition and thermo-mechanical properties of bonding can be engineered by chemical substitution. The results obtained allowed the determination of several necessary criteria for the development of chemically and mechanically stable diffusion barriers/couples for skutterudite based thermoelectric (TE) modules.
\end{abstract}

This invited article is part of a special tribute issue of the Journal of Phase Equilibria and Diffusion dedicated to the memory of Günter Effenberg. The special issue was organized by Andrew Watson, Coventry University, Coventry, United Kingdom; Svitlana Iljenko, MSI, Materials Science International Services GmbH, Stuttgart, Germany; and Rainer Schmid-Fetzer, Clausthal University of Technology, Clausthal-Zellerfield, Germany.

Electronic supplementary material The online version of this article (https://doi.org/10.1007/s11669-020-00799-0) contains supplementary material, which is available to authorized users.

Andriy Grytsiv

andriy.grytsiv@univie.ac.at

1 Institute of Materials Chemistry, University of Vienna, Währingerstr. 42, 1090 Vienna, Austria

2 Institute of Solid State Physics, TU Wien, Wiedner Hauptstr., 8-10, 1040 Vienna, Austria

3 Christian Doppler Laboratory for Thermoelectricity, Vienna, Austria
Keywords diffusion couples $\cdot$ electron probe microanalysis (EPMA) - intermetallics · phase diagram . skutterudites

\section{Introduction}

Thermoelectric (TE) energy conversion enables a direct transformation of heat into electricity. This technology has a great potential in various fields, like in waste heat recovery or in increasing the efficiency of industrial processes to not only reduce primary energy but also to minimize $\mathrm{CO}_{2}$ emissions. Besides tellurides, half-Heuslers, silicides, Zintl phases, oxides and more, skutterudites are most promising high efficient TE materials for middletemperature applications up to $600-700{ }^{\circ} \mathrm{C}$. To our knowledge, the highest dimensionless figure of merit (ZT) values for these bulk materials are $\mathrm{ZT}=1.4$ for p-type $\mathrm{DD}_{\mathrm{y}} \mathrm{Fe}_{3} \mathrm{CoSb}_{1.2}{ }^{[1]}$ (DD = didymium, a natural mixture of $\mathrm{Nd}$ and $\mathrm{Pr})$ and $\mathrm{ZT}=1.9$ for n-type $(\mathrm{Sr}, \mathrm{Ba}, \mathrm{Yb})_{\mathrm{y}} \mathrm{Co}_{4} \mathrm{Sb}_{12}{ }^{[2]}$ Skutterudites can be produced from relatively cheap and abundant starting materials, and commercial scale production for $\mathrm{p}-\mathrm{DD}_{\mathrm{y}} \mathrm{Fe}_{3} \mathrm{CoSb}_{12}\left(\mathrm{ZT}_{800 \mathrm{~K}}=1.2\right), \mathrm{p}-\mathrm{MM}_{\mathrm{y}} \mathrm{Fe}_{3-}$ $\mathrm{CoSb}_{12} \quad\left(\mathrm{ZT}_{800 \mathrm{~K}}=1.0\right), \quad$ and $\mathrm{n}-(\mathrm{MM}, \mathrm{Sm})_{\mathrm{y}} \mathrm{Co}_{4} \mathrm{Sb}_{12}$ $\left(\mathrm{ZT}_{800 \mathrm{~K}}=1.3\right)$ was established by Treibacher Industry AG (TIAG, Austria). With such high ZT values, and proven long term thermal stability ${ }^{[3]}$ a thermoelectric power generation already attracts interest for practical recuperation of waste heat into electricity, and requests the development of interface materials for durable TE modules.

A thermoelectric module is a complex set of different materials, which needs to be engineered in a highly sophisticated manner in order to provide a long term flawless and constant performance with respect to 
thermoelectric efficiency, which in turn directly depends on a chemically and metallurgically unaltered materials' constitution. The materials have to withstand thermal stresses, created due to rapid temperature cycling, and temperature gradients across the module, therefore the mechanical properties of TE materials are equally important, ${ }^{[4,5]}$ especially the coefficient of thermal expansion, as for skutterudites it is known that it differs for the p- and n-type alloys. ${ }^{[6]}$

Various pure metals and binary intermetallics (Fig. 1), ternary $\left(\mathrm{Fe}-\mathrm{Ni}-\mathrm{Cr}^{[7]}\right.$ and $\left.\mathrm{Co}-\mathrm{Fe}-\mathrm{Ni}^{[8]}\right)$, silicides $\mathrm{Co}-\mathrm{Si},{ }^{[9,10]}$ antimonides $\mathrm{Ni}-\mathrm{Sb},{ }^{[11]} \mathrm{Bi}_{2} \mathrm{Te}_{3}$-based $\mathrm{TE}$ materials ${ }^{[12]}$ and nitrides $\mathrm{TaN}^{[13,14]}$ were already used as contact materials for skutterudite-based TE modules.

These numerous investigations are mainly focused on the production and test of the TE durability of the TE modules. Various skutterudite compositions, contact materials and conditions have been tested, but systematic investigations of chemical aspects of the interaction of different materials with skutterudites are missing. We believe that fundamental information is requested for a successful development of durable skutterudite-based TE modules, as well as for a better understanding of the chemistry of these materials.

The current work is devoted to systematic investigations of interactions of skutterudites with different materials at the same conditions. Several materials were tested in view of two aspects: (a) ability of the elements to enter the skutterudite lattice (formation of skutterudites-structural chemical aspect) and (b) interaction of the contact materials with skutterudites and formation of intermediate phases (thermodynamic and phase equilibria aspects).

In this article we will report results of the interaction of the unfilled skutterudite $\mathrm{CoSb}_{3}$ with various pure metals. Then, the research was extended to single-filled
$\mathrm{n}-\mathrm{Ba}_{\mathrm{y}} \mathrm{Co}_{4} \mathrm{Sb}_{12}$ and $\mathrm{n}-\mathrm{Sr}_{\mathrm{y}} \mathrm{Co}_{4} \mathrm{Sb}_{12}, \mathrm{p}-\mathrm{Ce}_{\mathrm{y}} \mathrm{Fe}_{3} \mathrm{CoSb}_{12}$ and to multi-filled $\mathrm{p}-\mathrm{MM}_{\mathrm{y}} \mathrm{Fe}_{3} \mathrm{CoSb}_{12}(\mathrm{MM}=$ mischmetal, a natural mixture of $\mathrm{La}, \mathrm{Ce}, \mathrm{Pr}$ and $\mathrm{Nd}$ ). Finally, we report the test results of the interaction of binary intermetallics with filled skutterudites, and compare results with pure elements.

\section{Experimental Details}

Six compositions of skutterudites were used in the current investigation: unfilled $\mathrm{CoSb}_{3}$, n-type ${ }^{[23]}: \mathrm{Ba}_{0.3} \mathrm{Co}_{4} \mathrm{Sb}_{12}$ (named n1), $\mathrm{Sr}_{0.3} \mathrm{Co}_{4} \mathrm{Sb}_{12}$ (n2), $\mathrm{Ba}_{0.4} \mathrm{Co}_{4} \mathrm{Sb}_{12}$ (n3); and commercial p-types (Treibacher Industries AG, Austria, production 2008): $\mathrm{MMFe}_{3} \mathrm{CoSb}_{12}$ (p1) and $\mathrm{Ce}_{0.85} \mathrm{Fe}_{3}$ $\mathrm{CoSb}_{12}$, (p2, p3).

In a first step, the experiments on the interaction of pure elements and nitride TiN with the unfilled skutterudite $\mathrm{CoSb}_{3}$ were performed by means of powder metallurgical techniques. Powders were sieved to grain sizes of 20-50 $\mu \mathrm{m}$, and mixed with $\mathrm{CoSb}_{3}$ in a molar ratio 1:2 and then they were cold-pressed and heat-treated in evacuated quartz ampoules at $600{ }^{\circ} \mathrm{C}$ for 14 days. The product of interaction was investigated by means of $\mathrm{x}$-ray powder diffraction (XPD), collected from a HUBER-Guinier image plate with monochromatic $\mathrm{CuK}_{\alpha 1}$-radiation $(\lambda=0.154056 \mathrm{~nm})$.

Metals and intermetallics for the investigation of the diffusion couples were arc-melted on a water-cooled copper hearth in Ti-gettered argon from elemental ingots with a minimal purity better than 99 mass \%. The diameter of the so obtained pseudo-spherical specimens $(\varnothing=1.9$ $2.1 \mathrm{~mm}$ ) was measured and these balls were embedded into the skutterudite matrixes via hot-pressing (56 MPa, $600{ }^{\circ} \mathrm{C}, 2 \mathrm{~h}$ in $5 \mathrm{~N}$ Ar employing a uniaxial hot press

\begin{tabular}{|c|c|c|c|c|c|c|c|c|c|c|}
\hline Skutterudite/Contact & $\mathrm{Ag}$ & $\mathrm{Au}$ & $\mathrm{Cr}$ & Mo & $\mathrm{Ni}$ & Pd & $\mathrm{Pt}$ & $\mathrm{Ta}$ & $\overline{\mathrm{Ti}}$ & $\bar{v}$ \\
\hline \multicolumn{11}{|l|}{ n-type: } \\
\hline $\mathrm{CoSb}_{3}$ & & $a$ & & b & c & & $d$ & $\mathrm{e}$ & $f, A$ & e \\
\hline $\mathrm{Co}(\mathrm{Sb}, \mathrm{Sn}, \mathrm{Te})_{3}$ & & & & & g & g & & & $\mathrm{h}$ & \\
\hline $\ln _{y} \mathrm{Co}_{4} \mathrm{Sb}_{12}$ & & & & $\mathrm{i}, \mathrm{B}$ & i & & & & $\mathrm{j}, \mathrm{B}$ & \\
\hline $\mathrm{Yb}_{\mathrm{y}} \mathrm{Co}_{4} \mathrm{Sb}_{12}$ & $\mathrm{n}, \mathrm{C}$ & & $r$ & $\mathrm{k}, \mathrm{D}$ & 1 & $\mathrm{~m}$ & $n$ & & $\mathrm{o}, \mathrm{E}$ & \\
\hline$(\mathrm{Mm}, \mathrm{Sm})_{y} \mathrm{Co}_{4} \mathrm{Sb}_{2}$ & & & & & $\mathrm{~F}$ & & & & & \\
\hline \multicolumn{11}{|l|}{ p-type: } \\
\hline $\mathrm{Ce}_{\mathrm{y}}(\mathrm{Fe}, \mathrm{Co})_{4} \mathrm{Sb}_{12}$ & $\mathrm{n}, \mathrm{C}$ & & $r$ & e & $r$ & $\mathrm{~m}$ & $\mathrm{n}$ & $\mathrm{e}$ & $\mathrm{p}$ & e \\
\hline $\mathrm{Ce}_{\mathrm{y}}(\mathrm{Fe}, \mathrm{Mn})_{4} \mathrm{Sb}_{12}$ & & & & & 1 & & & & $\mathrm{I}, \mathrm{E}$ & \\
\hline$(\mathrm{Ce}, \mathrm{Yb})_{\mathrm{y}}(\mathrm{Fe}, \mathrm{Mn})_{4} \mathrm{Sb}_{12}$ & & & & & g & $g$ & & & & \\
\hline $\mathrm{DD}_{\mathrm{y}}(\mathrm{Fe}, \mathrm{Co})_{4} \mathrm{Sb}_{12}$ & & & & & $\mathrm{~F}$ & & & & & \\
\hline $\mathrm{MM}_{\mathrm{y}}(\mathrm{Fe}, \mathrm{Co})_{4} \mathrm{Sb}_{12}$ & & & & q & $G$ & & & & & \\
\hline
\end{tabular}

Fig. 1 Literature data on contact materials used for manufacturing of skutterudite based TE couples. Pure metals: a Ref 15, b Ref 9,15-17, c Ref 9,18,19, d Ref 15, e Ref 16, f Ref 15-17,20-25, g Ref 26, h 27, i 28, j Ref 29, k Ref 30,31, 1 Ref 32,33, m Ref 32, n Ref 32,34, o Ref
33,35, p Ref 16,20,25, q Ref 30, r Ref 32. Binaries: A (Al-Ti), ${ }^{[36]} \mathrm{B}$ (Mo-Ti), ${ }^{[29]} \mathrm{C}$ (Ag-Pd) ${ }^{[34]} \mathrm{D}$ (Mo-Ti) $,{ }^{[31,35]} \mathrm{E}(\mathrm{Al}-\mathrm{Ti}),{ }^{[7,37-39]} \mathrm{F}(\mathrm{Fe}-$ $\mathrm{Ni}){ }^{[40]} \mathrm{G}(\mathrm{Al}-\mathrm{Ni})^{[41]}$ 
W200/250-2200-200-KS). The tablets with a diameter of $10 \mathrm{~mm}$ were vacuum-sealed in quartz tubes and heattreated at $600{ }^{\circ} \mathrm{C}$ for $1100 \mathrm{~h}$. The annealed cylinders were ground to the appearance of the embedded balls, and then polished using standard procedures. Microstructure and chemical compositions were analysed by scanning electron microscopy/backscattered electrons (SEM/BSE) and electron probe microanalysis (EPMA) via an INCA Penta FETx3-Zeiss SUPRA ${ }^{\text {TM}}$ 55VP equipment with an EDX detector.

\subsection{Formation and General Consideration on Chemical Activity of the Skutterudites}

Skutterudites crystallise in the structure type of $\mathrm{CoAs}_{3}$ or $\mathrm{LaFe}_{4} \mathrm{P}_{12}$ (space group $\operatorname{Im} \overline{3}$ ), as a filled variant. The chemical formula of these compounds can be described as $E_{\mathrm{y}} T_{4} X_{12}$, where $T$ is a transition element of the VIII group in $8 c(1 / 4,1 / 4,1 / 4)$; the electropositive element $(E)$ occupies the icosahedral hole in $2 \mathrm{a}(0,0,0)$ which can be filled by a number of electropositive elements such as $\mathrm{Ca}, \mathrm{Sr}, \mathrm{Ba}, \mathrm{Tl}$, lanthanides and actinides, or under special conditions by $\mathrm{Y}$, $\mathrm{Hf}, \mathrm{Pb}$ and $\mathrm{Sn}$ (high pressure or multilayer precursor methods) and by $\mathrm{K}$ and $\mathrm{Na}$ (in nanowire state); $X$ is a pnicogen or one of the IVA-VIA elements in the $24 \mathrm{~g}$ site $(0, y, z)$. Some elements like $\mathrm{Sn}$ were found to be able to occupy the $24 \mathrm{~g}$ site $\left(\mathrm{Co}_{4} \mathrm{Sb}_{12-\mathrm{y}} \mathrm{Sn}_{\mathrm{y}}, \mathrm{CoSn}_{6} \mathrm{Te}_{6}\right.$, $\mathrm{La}_{1-\mathrm{x}} \mathrm{Co}_{4} \mathrm{Sb}_{12-\mathrm{y}} \mathrm{Sn}_{\mathrm{y}}, \quad \mathrm{Yb}_{1-\mathrm{x}} \mathrm{Co}_{4} \mathrm{Sb}_{12-\mathrm{y}} \mathrm{Sn}_{\mathrm{y}}, \quad \mathrm{Tl}_{1-\mathrm{x}} \mathrm{Co}_{4-}$ $\left.\mathrm{Sb}_{12-\mathrm{y}} \mathrm{Sn}_{\mathrm{y}}\right)$ as well as the $2 \mathrm{a}$ site $\left(\mathrm{Sn}_{\mathrm{y}} \mathrm{Ni}_{4} \mathrm{Sb}_{12-\mathrm{x}} \mathrm{Sn}_{\mathrm{x}}\right)$. The icosahedral cage in the skutterudite structure may be filled also by electronegative fillers such as $\mathrm{I}$ and $\mathrm{Br}$.

The ability of these elements to enter different positions in the crystal lattice of the skutterudite structure is shown in Fig. 2(a), and has to be used as guide for the selection of the materials being in contact with skutterudite in the TE module. Taking into account that all highlighted elements may substitute atoms in the skutterudite lattice, one may suggest exchange reactions between materials that contain these elements and skutterudites. Respectively TE properties in such diffusion zones will be affected. Our analysis on alloying skutterudites with different elements show that the strongest effect on the transport properties is observed in case of a substitution in the $24 \mathrm{~g}$ site. Therefore, elements, such as $\mathrm{Ga}$, In, Ge, $\mathrm{Sn}, \mathrm{Pb}, \mathrm{Se}$ and Te (site preference for $24 \mathrm{~g}$ ) as constituent for the contact materials should be used only in form of highly stable compounds that may warrant a low interaction with skutterudites. Metals of the VIII group (substitution of the 8c site) can be used when the diffusivity of these elements in the skutterudite lattice will be suppressed by additional intermediate phase(s) formed during the interaction. Elements in the empty cells (Fig. 2a) are not known to enter the skutterudite lattice and therefore, they are the most promising components for contact materials. Considering this, besides d-elements, we also investigated the interaction with such electrically and thermally conductive materials as graphite and titanium nitride.

\subsection{Interaction with Unfilled $\mathrm{CoSb}_{3}$}

Evaluation of the reaction products between pure elements and $\mathrm{CoSb}_{3}$ by means of $\mathrm{x}$-ray powder diffraction revealed an interaction in almost all cases: Ti, $\mathrm{Zr}$, Hf, V-medium/ strong interaction, $\mathrm{Nb}$ and $\mathrm{Ta}$-low interaction, with the exception of $\mathrm{W}, \mathrm{Re}$, graphite and $\mathrm{TiN}-$ no interaction. These observations (Fig. 2b) are in good correlation with the site preference in the skutterudite lattice (Fig. 2a), and with the constitution of the binary systems of these elements with antimony. The elements may be divided into five groups. The first group consists of noble metals (Mn, $\mathrm{Ru}, \mathrm{Pt}, \mathrm{Ag}$ and $\mathrm{Cu}$ ) that show a very strong interaction. Note that these elements are main constituents of high temperature brazing alloys and sometimes they are used for contacting skutterudite based TE modules. Such a strong interaction might be explained via the existence of a low temperature eutectic in the binary systems with antimony. Most likely a similar behaviour is valid for $\mathrm{Au}, \mathrm{Zn}$ and $\mathrm{Cd}$. The second group that shows a strong interaction consists mainly of 8th group's elements, which have the ability to occupy the $8 \mathrm{c}$ site in the skutterudite structure. Medium interaction was observed for the majority of metals from groups IV-VI that do not tend to replace atoms in the crystal lattice of the skutterudite and these elements form rather stable antimonides. No interaction was observed in case of $\mathrm{M}=\mathrm{W}, \mathrm{Re}$ and $\mathrm{C}$. This correlates with the absence of intermediate compounds in the binary M-Sb systems and ternary M-Co-Sb systems. Despite titanium interacting rather well with $\mathrm{CoSb}_{3}$, no interaction was observed for TiN, indicating that this compound coexists in a thermodynamic equilibrium with the skutterudite.

\subsection{Interaction of Filled Skutterudites with Pure Elements}

In a next step, our investigations were extended to the interaction of filled p-type skutterudites $\left(\mathrm{Ce}_{\mathrm{y}} \mathrm{Fe}_{3} \mathrm{CoSb}_{12}\right.$ and $\left.\mathrm{MM}_{\mathrm{y}} \mathrm{Fe}_{3} \mathrm{CoSb}_{12}\right)$ and n-type skutterudites $\left(\mathrm{Ba}_{\mathrm{y}} \mathrm{Co}_{4} \mathrm{Sb}_{12}\right.$ and $\mathrm{Sr}_{\mathrm{y}} \mathrm{Co}_{4} \mathrm{Sb}_{12}$ ) by means of diffusion couples. Phase constituents, their compositions and thickness of the reaction zone were determined by SEM (Fig. 3 and 4) and EPMA (Table 1). The thickness of the diffusion layer was measured as the distance from the initial ball to the phase boundary of the skutterudite matrix, however, it has to be noted that, in cases of interactions with elements that prefer to occupy the $8 \mathrm{c}$ crystallographic site (Fig. 2a), the 
Fig. 2 (a) Formation of skutterudites $\left(E_{\mathrm{y}} T_{4} X_{12}\right)$ and (b) interaction ability for TE skutterudites at $600{ }^{\circ} \mathrm{C}$

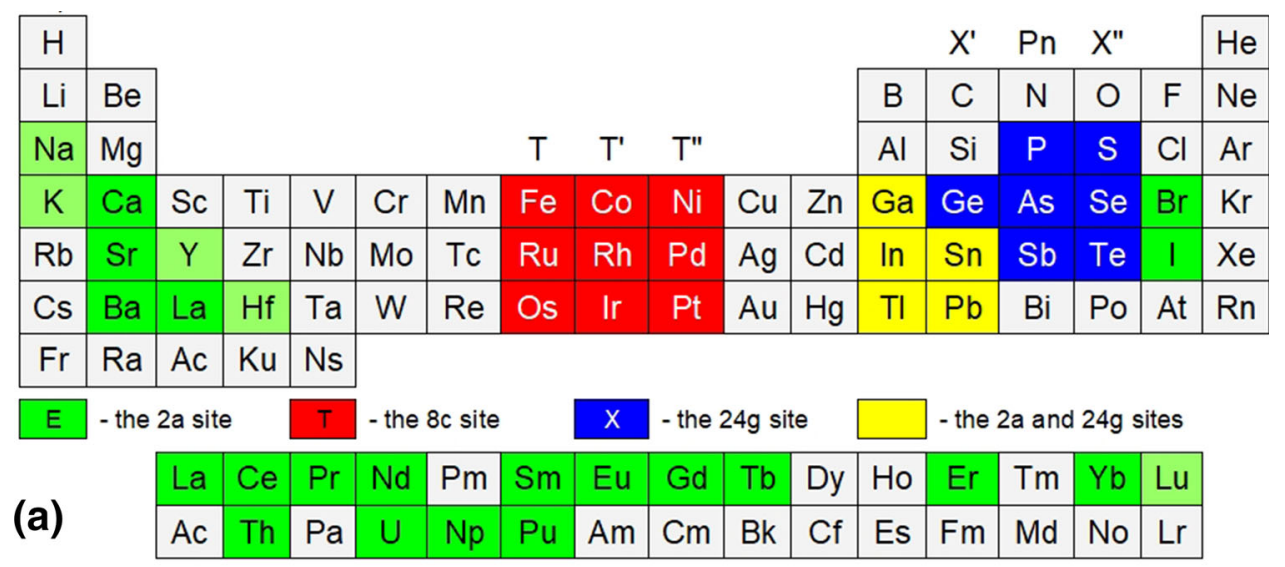

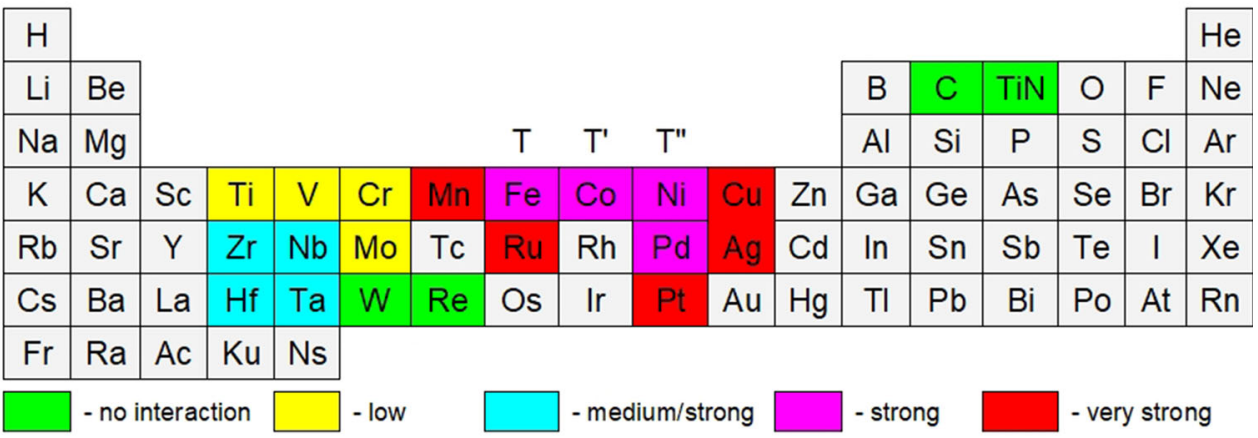

(b)

composition of the skutterudite matrix close to this phase boundary is significantly enriched by these elements. The thickness of this diffusion zone was not established due to the absence of a phase boundary. It is only possible to estimate an extension of this zone, which appears in SEM images as skutterudite matrix with increased density. The thickness of the diffusion layer was normalized by using the initial diameter of the balls and assuming their spherical shape. Thickness of the diffusion layer and phases formed during interaction and compositions of intermediate phases are listed in Table 1. As arbitrary characteristic for the quality of the diffusion layers we used the term "goodness" that includes thickness, porosity, formation of cracks and quality of the bonding to metal and skutterudite matrix. Solubility of the third component in the parent phases, which formed in the diffusion layer, was also accounted for in order to estimate the ability of the metals to diffuse into these phases. We have to note that the conditions used for the diffusion experiment (the spheroid metal specimens were embedded into the skutterudite matrix) produced much more thermo-mechanical stress (crack formation) in comparison to a planar contact between electrode and TE materials in the module.

Titanium A half-Heusler ( $\mathrm{HH})$ phase TiCoSb forms in contact with n-type skutterudite $\mathrm{Ba}_{0.3} \mathrm{Co}_{4} \mathrm{Sb}_{12}$ (Fig. 3a).
Furthermore, we observe a very extensive zone of $\mathrm{BaSb}_{3}$, $\mathrm{Ti}_{11-\mathrm{x}} \mathrm{Sb}_{8-\mathrm{y}}$ and very thin lavers, which, considering their brightness in backscatter electrons on SEM images and the constitution of the binary Ti-Sb phase diagram, ${ }^{[42]}$ might be attributed to $\mathrm{Ti}_{2} \mathrm{Sb}$ and $\mathrm{Ti}_{5} \mathrm{Sb}_{3}$. Note, that no binary $\mathrm{TiSb}$ and $\mathrm{TiSb}_{2}$ were determined in the diffusion zone being in good correlation with the constitution of the ternary system Ti-Co-Sb (Fig. 5a). The absence of TiSb most likely has its origin in particularities of phase equilibria in the quaternary system with $\mathrm{Ba}-\mathrm{Co}-\mathrm{Ti}-\mathrm{Sb}$, suggesting that equilibria with $\mathrm{BaSb}_{3}$ are more thermodynamically stable. In contrast to n-type, a thick layer of $\mathrm{TiSb}_{2}$ was detected in the diffusion zone, formed with $\mathrm{p}-\mathrm{MM}_{\mathrm{y}} \mathrm{Fe}_{3} \mathrm{CoSb}_{12}$ (Fig. 4). In addition, we observed the formation of $\mathrm{Ti}_{11-\mathrm{x}} \mathrm{Sb}_{8-\mathrm{y}}$ and $\mathrm{Ti}_{3} \mathrm{Sb}$, but not of TiSb.

Vanadium Almost all binary V-Sb phases ${ }^{[47]}$ formed in the diffusion zone. In addition, we detected the formation of an unreported compound, $\mathrm{Ba}_{5} \mathrm{~V}_{12} \mathrm{Sb}_{19+\mathrm{x}}$ for which the crystal structure was resolved to be isotypic with $\mathrm{Ba}_{5}$ $\mathrm{Ti}_{12} \mathrm{Sb}_{19+\mathrm{x}} \cdot{ }^{[48]}$ The thicknesses of the diffusion layers were about $40 \mu \mathrm{m}$; they were very dense and showed a good bonding to skutterudite and parent metals. A significant solubility of $\mathrm{Fe}$ and Co was observed only for binary $\mathrm{V}_{3} \mathrm{Sb}_{2}$ and " $\mathrm{V}_{5} \mathrm{Sb}_{4}$ ". Despite a big similarity in the phase equilibria in ternary systems (Ti,V)-Co-Sb (Fig. 5a and b), the 


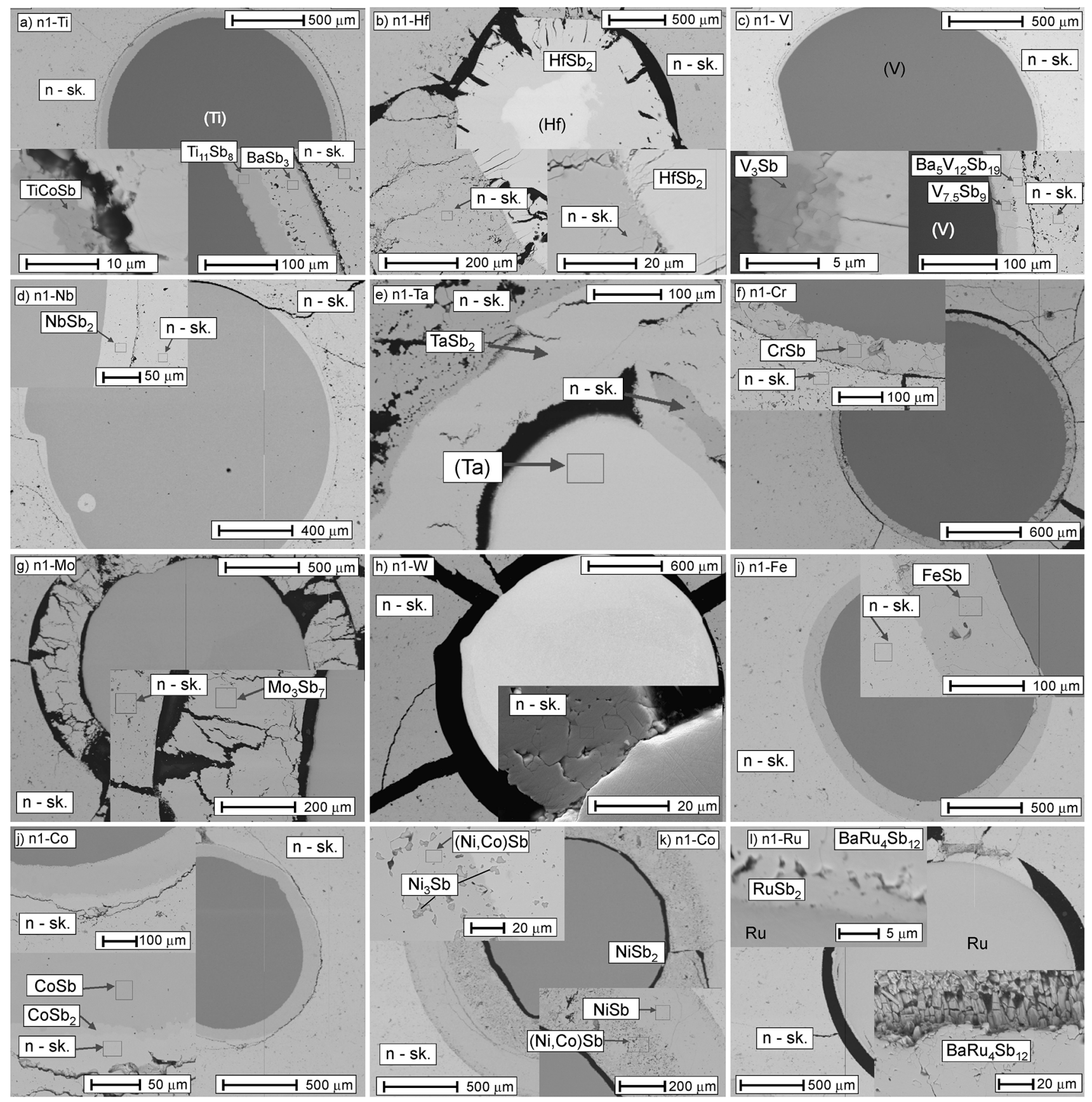

Fig. 3 SEM(BSE) images for diffusion couples with n-type skutterudites

constitution of the reaction zone differs significantly. Ternaries $\mathrm{Ba}_{5} \mathrm{M}_{12} \mathrm{Sb}_{19+\mathrm{x}}$ exist also with $\mathrm{Ti}$ and $\mathrm{Nb},{ }^{[48]}$ but we observed this structure only in the reaction couple with vanadium. In the other investigated systems binary antimonides and/or HH-phases were observed (Table 1) indicating that these phase equilibria are more energetically favourable.

Zirconium Both samples prepared with zirconium were lost during grinding. Probably, this happened due to almost no interaction (low bonding) with p- and n-type materials.
Hafnium, Niobium and Tantalum Only binary (Hf,Nb,Ta) $\mathrm{Sb}_{2}$ were detected in the reaction zone for both types of materials. These diffusion layers were rather dense, but brittle. The n-type material showed stronger interaction with $\mathrm{Hf}$ (higher thickness of the diffusion layer). A very similar constitution of the diffusion zone was observed for $\mathrm{Nb}$ and $\mathrm{Ta}$, but the thickness of the $\mathrm{MSb}_{2}$ layer was significantly lower (Table 1). The presence of $\mathrm{MSb}_{2}$ in the diffusion zone is in accordance with the ternary systems (Hf,Nb)-Co-Sb (Fig. 4c and d, no phase 


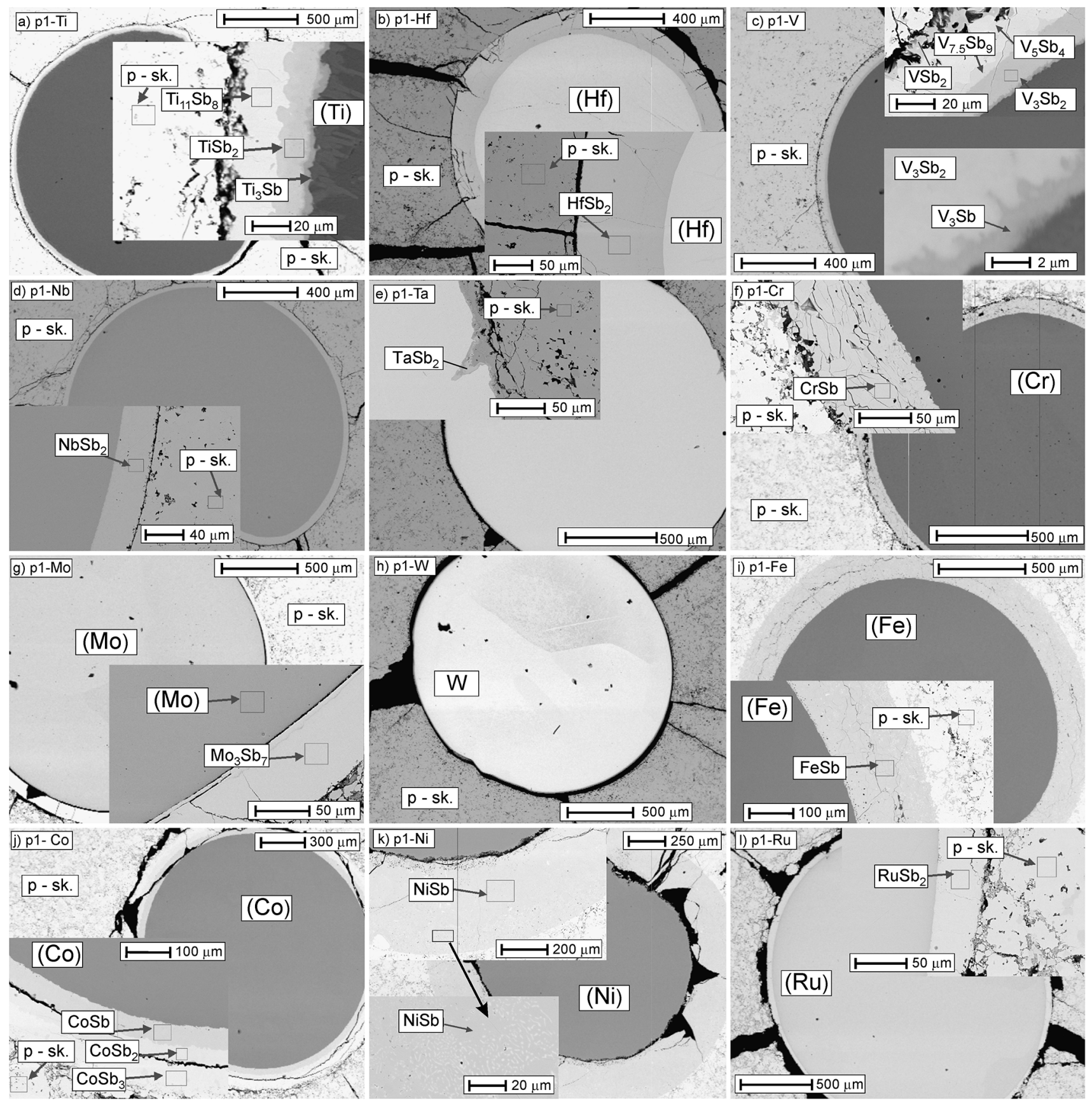

Fig. 4 SEM(BSE) images for diffusion couples with p-type skutterudites

diagram is known for Ta-Co-Sb) and shows that the equilibrium $\mathrm{MCoSb}-\mathrm{MSb}_{2}$ separates $\mathrm{CoSb}_{3}$ from the equilibria with other phases. This phase equilibrium is not present in the ternary systems (Ti,V)-Co-Sb (Fig. 4a and b) indicating that the binary phases $(\mathrm{Zr}, \mathrm{Nb}, \mathrm{Ta}) \mathrm{Sb}_{2}$ are efficient diffusion barriers. Furthermore, the reduced thickness of the interaction zone for the samples with niobium and tantalum indicated that the low symmetry monoclinic structure of binary $(\mathrm{Nb}, \mathrm{Ta}) \mathrm{Sb}_{2}$ (OsGe $\mathrm{Os}_{2}$-structure type) is more resistant against diffusion of foreign atoms than both, orthorhombic ( $\mathrm{Zr}, \mathrm{Hf}) \mathrm{Sb}_{2} \quad\left(\mathrm{TiAs}_{2}\right.$-structure type) and tetragonal $(\mathrm{Ti}, \mathrm{V}) \mathrm{Sb}_{2}\left(\mathrm{CuAl}_{2}\right.$-structure type). A small solubility of the third element was measured in all these phases, which could indicate a suppressed ability for foreign elements to diffuse through these crystal lattices. In addition to these two aspects (phase equilibria and crystal structure), there is also a certain correlation between thickness of diffusion layers $\mathrm{MSb}_{2}$ and melting points of these compounds: $\mathrm{VSb}_{2}\left(869^{\circ} \mathrm{C}\right),(\mathrm{Nb}, \mathrm{Ta}) \mathrm{Sb}_{2}\left(1089{ }^{\circ} \mathrm{C}\right)$, 
Table 1 Interaction of p- and n-type skutterudites with various metals, and constitution of the diffusion layer after anneal at $600{ }^{\circ} \mathrm{C}$ for $1100 \mathrm{~h}$

\begin{tabular}{|c|c|c|c|c|}
\hline Couple $^{\mathrm{a}}$ & $l^{\mathrm{b}}$ & Figure & $\mathrm{G}^{\mathrm{c}}$ & Intermediate phases (compositions from EPMA in at.\%) \\
\hline n1-Ti & 75 & $3 \mathrm{a}$ & Good & $\mathrm{TiCoSb}\left(\mathrm{Ti}_{34.1} \mathrm{Co}_{31.8} \mathrm{Sb}_{34.1}\right), \mathrm{BaSb}_{3}\left(\mathrm{Ba}_{26} \mathrm{Sb}_{74}\right), \mathrm{Ti}_{11} \mathrm{Sb}_{8}\left(\mathrm{Ti}_{57.5} \mathrm{Sb}_{42.5}\right)$ \\
\hline p1-Ti & 30 & $4 a$ & Good & $\mathrm{TiSb}_{2}\left(\mathrm{Ti}_{32.0} \mathrm{Fe}_{0.7} \mathrm{Sb}_{67.3}\right), \mathrm{Ti}_{11} \mathrm{Sb}_{8}\left(\mathrm{Ti}_{56.6} \mathrm{Fe}_{2.1} \mathrm{Sb}_{41.3}\right), \mathrm{Ti}_{3} \mathrm{Sb}\left(\mathrm{Ti}_{77.8} \mathrm{Sb}_{22.2}\right)$ \\
\hline n1-Hf & $\sim 200$ & $3 b$ & Brittle & $\mathrm{HfSb}_{2}\left(\mathrm{Hf}_{35.2} \mathrm{Co}_{0.6} \mathrm{Sb}_{64.2}\right)$ \\
\hline $\mathrm{p} 1-\mathrm{Hf}$ & 90 & $4 \mathrm{~b}$ & Good & $\mathrm{HfSb}_{2}\left(\mathrm{Hf}_{33.8} \mathrm{Fe}_{1.9} \mathrm{Co}_{0.9} \mathrm{Sb}_{63.4}\right)$ \\
\hline $\mathrm{n} 1-\mathrm{V}$ & 40 & $3 \mathrm{c}$ & Good & $\mathrm{V}_{3} \mathrm{Sb}\left(\mathrm{V}_{74} \mathrm{Sb}_{26}\right), \mathrm{V}_{7.5} \mathrm{Sb}_{9}\left(\mathrm{~V}_{44.4} \mathrm{Sb}_{55.6}\right), \mathrm{Ba}_{5} \mathrm{~V}_{12} \mathrm{Sb}_{19}\left(\mathrm{Ba}_{13.8} \mathrm{~V}_{31.5} \mathrm{Sb}_{54.7}\right)$ \\
\hline p1-V & 40 & $4 \mathrm{c}$ & Good & $\begin{array}{l}\mathrm{V}_{3} \mathrm{Sb}\left(\mathrm{V}_{80.4} \mathrm{Fe}_{3.7} \mathrm{Sb}_{15.9}\right), \mathrm{V}_{3} \mathrm{Sb}_{2}\left(\mathrm{~V}_{50.9} \mathrm{Fe}_{9.2} \mathrm{Sb}_{39.9}\right), \mathrm{V}_{5} \mathrm{Sb}_{4}\left(\mathrm{~V}_{40.5} \mathrm{Fe}_{15.6} \mathrm{Sb}_{43.9}\right) \\
\quad \mathrm{V}_{7.5} \mathrm{Sb}_{9}\left(\mathrm{~V}_{41.2} \mathrm{Fe}_{3.2} \mathrm{Co}_{0.6} \mathrm{Sb}_{55.0}\right), \mathrm{VSb}_{2}\left(\mathrm{~V}_{32.1} \mathrm{Sb}_{67.9}\right)\end{array}$ \\
\hline $\mathrm{n} 1-\mathrm{Nb}$ & 40 & $3 \mathrm{~d}$ & Good & $\mathrm{NbSb}_{2}\left(\mathrm{Nb}_{33.8} \mathrm{Sb}_{66.2}\right)$ \\
\hline $\mathrm{p} 1-\mathrm{Nb}$ & 30 & $4 d$ & Good & $\mathrm{NbSb}_{2}\left(\mathrm{Nb}_{33.7} \mathrm{Sb}_{66.3}\right)$ \\
\hline n1-Ta & 60 & $3 \mathrm{e}$ & Good & $\mathrm{TaSb}_{2}\left(\mathrm{Ba}_{0.9} \mathrm{Ta}_{34.9} \mathrm{Co}_{1.0} \mathrm{Sb}_{63.2}\right)$ \\
\hline $\mathrm{p} 1-\mathrm{Ta}$ & $2-5$ & $4 \mathrm{e}$ & - & Little interaction \\
\hline n1-Cr & 70 & $3 \mathrm{f}$ & Brittle & $\mathrm{CrSb}\left(\mathrm{Cr}_{48.8} \mathrm{Sb}_{51.2}\right)$ \\
\hline $\mathrm{p} 1-\mathrm{Cr}$ & 70 & $4 \mathrm{f}$ & Brittle & $\mathrm{CrSb}\left(\mathrm{Cr}_{48.4} \mathrm{Sb}_{51.6}\right)$ \\
\hline n1-Mo & $\sim 200$ & $3 g$ & Brittle & $\mathrm{Mo}_{3} \mathrm{Sb}_{7}\left(\mathrm{Mo}_{30.7} \mathrm{Sb}_{69.3}\right)$ \\
\hline p1-Mo & 65 & $4 g$ & Brittle & $\mathrm{Mo}_{3} \mathrm{Sb}_{7}\left(\mathrm{Mo}_{31.3} \mathrm{Sb}_{68.7}\right)$ \\
\hline $\mathrm{n} 1-\mathrm{W}$ & $\sim 0$ & $3 \mathrm{~h}$ & - & No interaction \\
\hline p1-W & $\sim 0$ & $4 \mathrm{~h}$ & - & No interaction \\
\hline $\mathrm{n} 1-\mathrm{Fe}$ & 100 & $3 \mathrm{i}$ & Good & $\mathrm{FeSb}\left(\mathrm{Ba}_{0.4} \mathrm{Fe}_{44.8} \mathrm{Co}_{8.6} \mathrm{Sb}_{46.2}\right)$ \\
\hline $\mathrm{n} 2-\mathrm{Fe}$ & 100 & & & $\mathrm{FeSb}\left(\mathrm{Fe}_{55.0} \mathrm{Sb}_{45.0}\right), \mathrm{CoSb}_{2}\left(\mathrm{Fe}_{1.5} \mathrm{Co}_{32.0} \mathrm{Sb}_{66.5}\right)$ \\
\hline $\mathrm{n} 3-\mathrm{Fe}$ & 130 & & & $\mathrm{FeSb}\left(\mathrm{Fe}_{54.3} \mathrm{Sb}_{45.7}\right)$ \\
\hline $\mathrm{p} 1-\mathrm{Fe}$ & 170 & $4 \mathrm{i}$ & Good & $\mathrm{FeSb}\left(\mathrm{Fe}_{53.6} \mathrm{Sb}_{46.4}\right)$ \\
\hline $\mathrm{p} 2-\mathrm{Fe}$ & 200 & & & $\mathrm{FeSb}\left(\mathrm{Fe}_{54.1} \mathrm{Sb}_{45.9}\right)$ \\
\hline $\mathrm{p} 3-\mathrm{Fe}$ & 155 & & & $\mathrm{FeSb}\left(\mathrm{Fe}_{53.2} \mathrm{Sb}_{46.8}\right), \mathrm{FeSb}_{2}\left(\mathrm{Fe}_{33.0} \mathrm{Sb}_{67.0}\right)$ \\
\hline n1-Co & 130 & $3 \mathrm{j}$ & Good & $\mathrm{CoSb}\left(\mathrm{Co}_{49.0} \mathrm{Sb}_{51.0}\right), \mathrm{CoSb}_{2}\left(\mathrm{Co}_{32.5} \mathrm{Sb}_{67.5}\right)$ \\
\hline n2-Co & 80 & & & $\mathrm{CoSb}\left(\mathrm{Sr}_{1.0} \mathrm{Co}_{49.1} \mathrm{Sb}_{49.9}\right)$ \\
\hline n3-Co & 140 & & & $\mathrm{CoSb}\left(\mathrm{Co}_{50.4} \mathrm{Sb}_{49.6}\right)+\mathrm{CoSb}_{3}\left(\mathrm{Co}_{24.7} \mathrm{Sb}_{75.3}\right)$ \\
\hline p1-Co & 120 & $4 j$ & Good & $\mathrm{CoSb}\left(\mathrm{Fe}_{2.0} \mathrm{Co}_{48.3} \mathrm{Sb}_{49.7}\right), \mathrm{CoSb}_{2}\left(\mathrm{Fe}_{7.2} \mathrm{Co}_{26.1} \mathrm{Sb}_{66.7}\right), \mathrm{CoSb}_{3}\left(\mathrm{Co}_{20.4} \mathrm{Fe}_{4.5} \mathrm{Sb}_{75.1}\right)$ \\
\hline p2-Co & 100 & & & $\mathrm{FeSb}\left(\mathrm{Fe}_{3.0} \mathrm{Co}_{47.3} \mathrm{Sb}_{49.7}\right), \mathrm{CoSb}_{2}\left(\mathrm{Fe}_{6.7} \mathrm{Co}_{27.46} \mathrm{Sb}_{65.85}\right)$ \\
\hline p3-Co & 190 & & & $\begin{array}{l}\mathrm{CoSb}\left(\mathrm{Ce}_{0.5} \mathrm{Fe}_{1.1} \mathrm{Co}_{49.2} \mathrm{Sb}_{49.2}\right), \mathrm{CoSb}_{2}\left(\mathrm{Fe}_{3.2} \mathrm{Co}_{31.3} \mathrm{Sb}_{65.5}\right), \mathrm{FeSb}_{2} \\
\quad\left(\mathrm{Ce}_{0.6} \mathrm{Fe}_{28.2} \mathrm{Co}_{6.7} \mathrm{Sb}_{64.5}\right), \mathrm{CoSb}_{3}\left(\mathrm{Fe}_{3.6} \mathrm{Co}_{22.6} \mathrm{Sb}_{73.8}\right)\end{array}$ \\
\hline n1-Ni & $\sim 500$ & $3 \mathrm{k}$ & Good & $\begin{array}{l}\mathrm{NiSb}\left(\mathrm{Ni}_{43.34} \mathrm{Co}_{9.19} \mathrm{Sb}_{47.47}\right),(\mathrm{Ni}, \mathrm{Co}) \mathrm{Sb}\left(\mathrm{Ba}_{0.5} \mathrm{Ni}_{26.8} \mathrm{Co}_{21.7} \mathrm{Sb}_{51.0}\right), \mathrm{Ni}_{3} \mathrm{Sb} \\
\quad\left(\mathrm{Co}_{2.7} \mathrm{Ni}_{70.1} \mathrm{Sb}_{27.2}\right)\end{array}$ \\
\hline $\mathrm{n} 2-\mathrm{Ni}$ & 520 & & & $(\mathrm{Ni}, \mathrm{Co}) \mathrm{Sb}\left(\mathrm{Co}_{20.5} \mathrm{Ni}_{29.8} \mathrm{Sb}_{49.7}\right)$ \\
\hline $\mathrm{n} 3-\mathrm{Ni}$ & 470 & & & $\mathrm{Ni}_{3} \mathrm{Sb}\left(\mathrm{Co}_{2.3} \mathrm{Ni}_{69.4} \mathrm{Sb}_{28.3}\right), \mathrm{NiSb}\left(\mathrm{Co}_{2.2} \mathrm{Ni}_{50.8} \mathrm{Sb}_{47.0}\right)$ \\
\hline $\mathrm{p} 1-\mathrm{Ni}$ & $\sim 300$ & $4 \mathrm{k}$ & Good & $\mathrm{NiSb}\left(\mathrm{Ni}_{49 \div 40} \mathrm{Co}_{2 \div 5} \mathrm{Fe}_{1 \div 7} \mathrm{Sb}_{48 \div 50}\right),(\mathrm{Fe}, \mathrm{Ni}) \mathrm{Sb}_{2}\left(\mathrm{Fe}_{19.5} \mathrm{Co}_{4.5} \mathrm{Ni}_{10.7} \mathrm{Sb}_{65.3}\right)$ \\
\hline $\mathrm{p} 2-\mathrm{Ni}$ & 320 & & & $\mathrm{NiSb}\left(\mathrm{Fe}_{2.3} \mathrm{Co}_{2.2} \mathrm{Ni}_{53.0} \mathrm{Sb}_{42.5}\right)-\left(\mathrm{Ce}_{3.9} \mathrm{Co}_{2.0} \mathrm{Ni}_{50.5} \mathrm{Sb}_{43.7}\right)$ \\
\hline p3-Ni & 300 & & & $\mathrm{NiSb}\left(\mathrm{Fe}_{5.5} \mathrm{Co}_{2.8} \mathrm{Ni}_{42 .}{ }_{6} \mathrm{Sb}_{49.1}\right),(\mathrm{Fe}, \mathrm{Ni}) \mathrm{Sb}_{2}\left(\mathrm{Fe}_{20.2} \mathrm{Co}_{4.5} \mathrm{Ni}_{10.0} \mathrm{Sb}_{65.3}\right)$ \\
\hline $\mathrm{n} 1-\mathrm{Ru}$ & $\sim 100$ & 31 & Good & $\mathrm{BaRu}_{4} \mathrm{Sb}_{12}\left(\mathrm{Ba}_{5.9} \mathrm{Ru}_{24.3} \mathrm{Sb}_{69.8}\right), \mathrm{RuSb}_{2}\left(\mathrm{Ru}_{34.1} \mathrm{Sb}_{65.9}\right)$ \\
\hline $\mathrm{p} 1-\mathrm{Ru}$ & $\sim 40$ & 41 & Good & $\mathrm{RuSb}_{2}\left(\mathrm{Ru}_{27.7} \mathrm{Fe}_{5.2} \mathrm{Sb}_{67.1}\right)$ \\
\hline n1-Pd & $\infty$ & $\cdots$ & $\cdots$ & Pd was completely dissolved in skutterudite \\
\hline p1-Pd & $\infty$ & $\cdots$ & $\cdots$ & $\mathrm{PdSb}\left(\mathrm{La}_{1} \mathrm{Ce}_{2} \mathrm{Nd}_{1} \mathrm{Pd}_{32 \div 35} \mathrm{Fe}_{11 \div 9} \mathrm{Co}_{4} \mathrm{Sb}_{49}\right), \mathrm{PdSb}_{2}\left(\mathrm{La}_{1} \mathrm{Ce}_{3} \mathrm{Nd}_{1} \mathrm{Fe}_{15} \mathrm{Pd}_{11} \mathrm{Co}_{6} \mathrm{Sb}_{63}\right)$ \\
\hline n1-Pt & $\sim 450$ & $\cdots$ & $\cdots$ & $\begin{array}{l}\mathrm{CoSb}\left(\mathrm{Ba}_{0.3} \mathrm{Co}_{46.2} \mathrm{Pt}_{1.4} \mathrm{Sb}_{52.1}\right), \mathrm{PtSb}_{2}\left(\mathrm{Ba}_{1} \mathrm{Pt}_{34} \mathrm{Co}_{3} \mathrm{Sb}_{62}\right), " \mathrm{Pt}_{5} \mathrm{Sb}_{4} "\left(\mathrm{Pt}_{49.7} \mathrm{Co}_{5.5} \mathrm{Sb}_{44.7}\right), \\
\quad \mathrm{Pt}_{6.7} \mathrm{Sb}_{1.3}\left(\mathrm{Pt}_{77.7} \mathrm{Co}_{6.4} \mathrm{Sb}_{15.9}\right), " \mathrm{Pt}_{2} \mathrm{Sb}\left(\mathrm{Pt}_{62.8} \mathrm{Co}_{5.8} \mathrm{Sb}_{31.4}\right)\end{array}$ \\
\hline $\mathrm{p} 1-\mathrm{Pt}$ & $\sim 500$ & $\cdots$ & $\ldots$ & 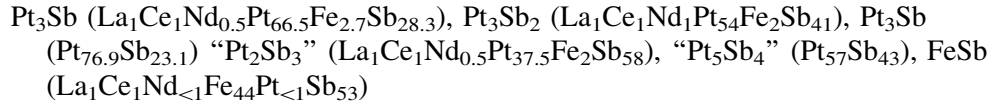 \\
\hline
\end{tabular}

${ }^{a}$ n-type: $\mathrm{Ba}_{0.3} \mathrm{Co}_{4} \mathrm{Sb}_{12}$ (n1), $\mathrm{Sr}_{0.3} \mathrm{Co}_{4} \mathrm{Sb}_{12}$ (n2), $\mathrm{Ba}_{0.4} \mathrm{Co}_{4} \mathrm{Sb}_{12}(\mathrm{n} 3)$; p-type: $\mathrm{MMFe}_{3} \mathrm{CoSb}_{12}$ (p1) and $\mathrm{Ce}_{0.85} \mathrm{Fe}_{3} \mathrm{CoSb}_{12},(\mathrm{p} 2, \mathrm{p} 3)$

$\mathrm{b}$ Thickness of the diffusion layer $(\mu \mathrm{m})$, normalized to the maximal cross section of the metal ball

${ }^{c}$ Goodness of interaction layer 

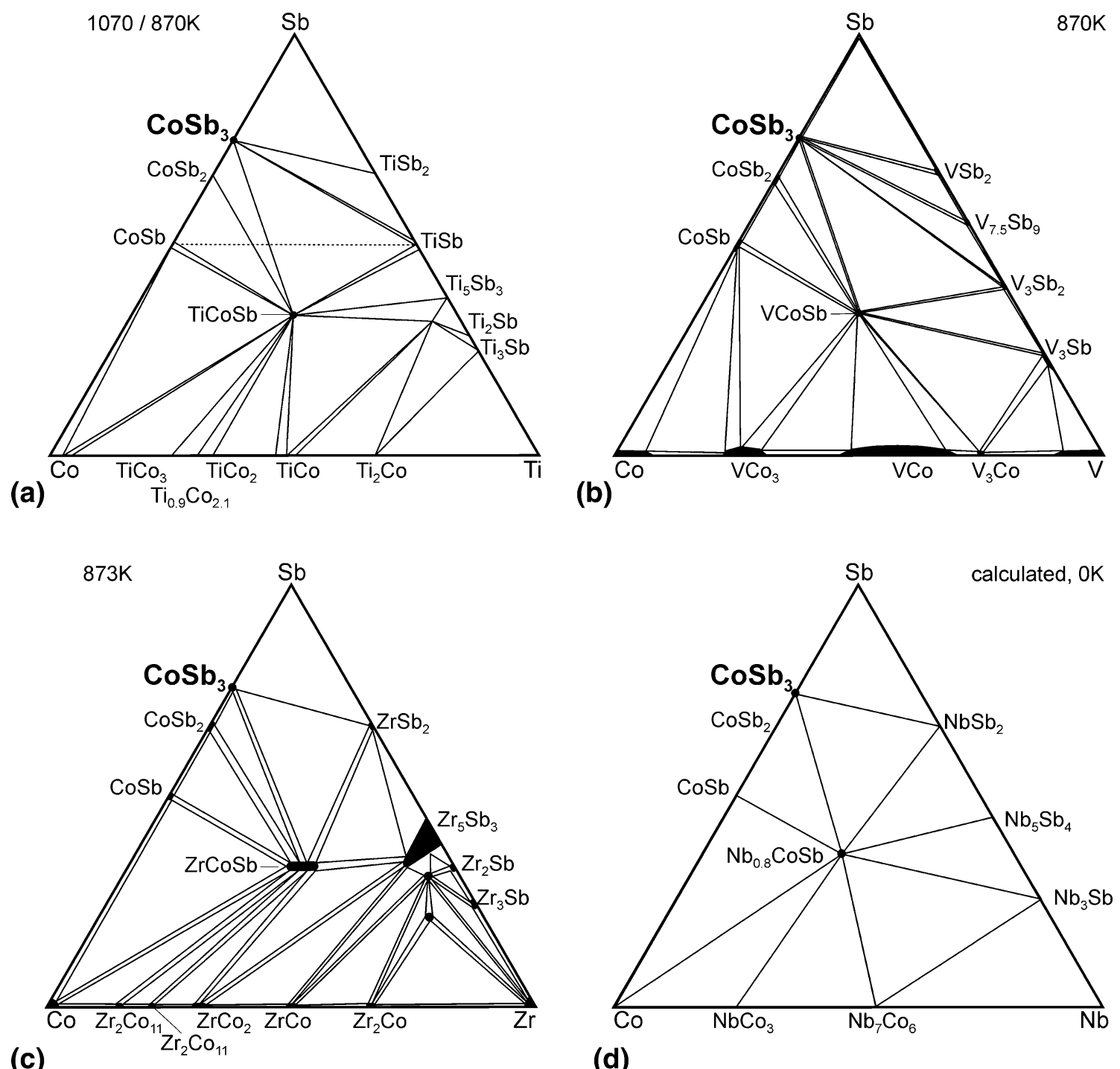

(d)

Fig. 5 Phase equilibria in ternary systems $\mathrm{M}-\mathrm{Co}-\mathrm{Sb}$ : (a) $\mathrm{M}=\mathrm{Ti},{ }^{[43]}$ (b) $\mathrm{M}=\mathrm{V},{ }^{[44]}$ (c) $\mathrm{M}=\mathrm{Zr}^{[45]}$ and (d) $\mathrm{M}=\mathrm{Nb}^{[46]}$

$\mathrm{TiSb}_{2} \quad\left(1051^{\circ} \mathrm{C}\right), \quad \mathrm{ZrSb}_{2} \quad\left(1363{ }^{\circ} \mathrm{C}\right) \quad$ and $\quad \mathrm{HfSb}_{2}$ $\left(980{ }^{\circ} \mathrm{C}\right) .^{[42,47]}$

Chromium Diffusion zones with a thickness of about $70 \mu \mathrm{m}$ consisted of $\mathrm{CrSb}$. No Fe or Co was detected in the diffusion layer. The diffusion layer was very brittle.

Molybdenum Brittle diffusion layers of $\mathrm{Mo}_{3} \mathrm{Sb}_{7}$ with relatively good bonding ability were observed. No other binary molybdenum antimonides are known.

Tungsten No interaction was observed. Due to a significant mismatch of thermal expansion coefficients big cracks formed in the skutterudite matrix.

Iron, Cobalt and Nickel These elements showed a very strong interaction with $\mathrm{p}$ - and n-skutterudites. Diffusion layers with a thickness in the range of 100-200 $\mu \mathrm{m}$ were observed for $\mathrm{Fe}$ and $\mathrm{Co}$ whilst the interaction zone expanded up to $500 \mu \mathrm{m}$ for $\mathrm{Ni}$. Despite these extensive diffusion layers, we want to emphasize the good quality of the contact between the diffusion layer and the skutterudites. The composition of the skutterudites near the boundary of the reaction zone shifted due to the $\mathrm{Fe} / \mathrm{Co} / \mathrm{Ni}$ substitution in the $8 \mathrm{c}$ site with a respective change of the filling level in the $2 \mathrm{a}$ site. This exchange results in the formation of an additional quantity of the skutterudite that diminishes the porosity of the initial skutterudite matrix.

Ruthenium A strong interaction with the formation of $\mathrm{RuSb}_{2}$ and $\mathrm{Fe} / \mathrm{Co} / \mathrm{Ru}$ substitution was found. For the n-type material we observe a complete substitution with the formation of $\mathrm{BaRu}_{4} \mathrm{Sb}_{12}$. The diffusion layer was rather thin (below $100 \mu \mathrm{m}$ ) and well bonded to $(\mathrm{Ru})$ but the contact to the skutterudite matrix was poor.

Palladium and Platinum Both noble metals showed a very strong interaction with skutterudites. Palladium balls were completely resolved in the skutterudite matrix. The interaction of the platinum with skutterudites was similar to 
that observed for nickel, and resulted in a very thick diffusion zone with numerous phases (Table 1).

\subsection{Interaction of Filled Skutterudites with Binary Compositions}

Thermal expansion coefficients for the metals, that show a low interaction with skutterudites, are significantly lower $\left(\alpha=5 \div 9 \times 10^{-6} \mathrm{~K}^{-1}\right)$ than typical for p-type skutterudites $\left(\alpha=11 \div 12 \times 10^{-6} \mathrm{~K}^{-1}\right)$ and are closer to that of n-type $\left(\alpha=8 \div 9 \times 10^{-6} \mathrm{~K}^{-1}\right){ }^{[6]}$ Only TiN has a thermal expansion coefficient $\left(\alpha=9.4 \times 10^{-6} \mathrm{~K}^{-1}\right)$ that fits rather well with both types of the TE materials, and this suggests necessarily development of individual diffusion barriers for different types of TE-legs.

A significant mismatch in the thermal expansion coefficients of the materials is a main problem for the thermomechanical stability of the bonding, and it could be that materials which are effective protective barriers will not be suitable for practical application. Taking into account that thermal expansion might be adjusted by chemical substitution, our next experiment concerned binary compositions formed by elements that have low thermal expansion coefficients and did not enter the skutterudite lattice (Ti, V, $\mathrm{Nb}, \mathrm{Ta}, \mathrm{Cr}, \mathrm{Mo}, \mathrm{W}$ ) with those that form skutterudites, but have a high bonding compatibility and high thermal expansion coefficients ( $\mathrm{Fe}, \mathrm{Co}$ and $\mathrm{Ni} ; \alpha \approx 13 \times$ $10^{-6} \mathrm{~K}^{-1}$ ).

The thickness of the diffusion layer and the bonding ability to skutterudites were compared with those observed for pure metals. Binary eutectics were used as compositions for this investigation, and in the cases of absence of eutectics ( $\mathrm{V}-\mathrm{Fe}$ and $\mathrm{Fe}-\mathrm{Cr}$ ), we used solid solutions. Structures of the diffusion zones with $\mathrm{p}-$ and n-skutterudites are shown in Figures S1-S3 (Supplementary Information); the thickness of the diffusion zones is listed in Table 2. The quality of the interface between the diffusion zones and skutterudites/alloys was improved in almost all cases compared to those with pure elements (Fig. 3 and 4 and Table 1), and this effect we attribute to a better matching of the thermal expansion coefficients of the bonded materials. Effect of the alloying on the thickness of the interaction layer is rather different for $\mathrm{p}$ - and n-type materials. Dependences (Fig. $6 \mathrm{c}$ and $\mathrm{d}$ and 7) are not smooth, because the solid solutions exists only in the binary systems $\mathrm{Fe}-\mathrm{V}$ and $\mathrm{Fe}-\mathrm{Cr}$, whilst the other investigated systems contain various phases with different interaction ability. Therefore, lines connecting experimental points in Fig. 6 and 7 are shown only as guides for the eyes.

The strongest ability to suppress interaction and diffusion was observed for binary alloys with $\mathrm{V}, \mathrm{Nb}$ and $\mathrm{Ta}$. A beneficial effect was observed for the n-type materials, for which in most cases the thickness of the diffusion zone was lower than for pure metals. A strong suppression of the interaction with n-type materials was also observed in case of $\mathrm{Co}_{72} \mathrm{Mo}_{28}, \mathrm{Ni}_{44} \mathrm{Cr}_{56}$ and $\mathrm{Co}_{59} \mathrm{Cr}_{41}$. Note, that the effect of $\mathrm{W}$-alloying on the suppression of the interaction is not as strong as one may suggest, considering the absence of an interaction between skutterudites and pure tungsten. The same concerns exist for the interaction of $\mathrm{Nb}$ depleted compositions with p-type materials (Fig. 6d). Whilst alloying by this element has generally a very beneficial effect, these two phase compositions interact with p-skutterudite even stronger than pure elements. This deteriorative effect cannot be explained only by particularities of the crystal structure of the second phase in these samples. Niobium-based binary Laves phases (with $\mathrm{MgNi}_{2}$ and $\mathrm{MgZn}_{2}$ type) coexist in equilibria with $(\mathrm{Co})$ and $(\mathrm{Fe})$ whilst
Table 2 Interaction of the skutterudites with binary alloys ( $\mathrm{Fe}, \mathrm{Co}, \mathrm{Ni})-$

(Ti,V,Nb,Ta,Cr,Mo,W), and constitution of the diffusion layer after annealing at $600{ }^{\circ} \mathrm{C}$ for $1100 \mathrm{~h}$

\begin{tabular}{lllllllll}
\hline Materials & $l_{n}, \mu \mathrm{m}$ & $l_{p}, \mu \mathrm{m}$ & Materials & $l_{n}, \mu \mathrm{m}$ & $l_{p}, \mu \mathrm{m}$ & Materials & $l_{n}, \mu \mathrm{m}$ & $l_{p}, \mu \mathrm{m}$ \\
\hline $\mathrm{Fe}_{84} \mathrm{Ti}_{16}$ & 210 & 95 & $\mathrm{Co}_{76} \mathrm{Ti}_{24}$ & 790 & 155 & $\mathrm{Ni}_{83} \mathrm{Ti}_{17}$ & 275 & 80 \\
$\mathrm{Fe}_{30} \mathrm{Ti}_{70}$ & 200 & 100 & $\mathrm{Co}_{23} \mathrm{Ti}_{77}$ & 170 & 162 & $\mathrm{Ni}_{61} \mathrm{Ti}_{39}$ & 360 & 50 \\
$\mathrm{Fe}_{70} \mathrm{~V}_{30}$ & 7 & 60 & $\mathrm{Co}_{59} \mathrm{~V}_{41}$ & 20 & 36 & $\mathrm{Ni}_{24} \mathrm{Ti}_{76}$ & 95 & 100 \\
$\mathrm{Fe}_{88} \mathrm{Nb}_{12}$ & 70 & 235 & $\mathrm{Co}_{87} \mathrm{Nb}_{13}$ & 55 & 179 & $\mathrm{Ni}_{49} \mathrm{~V}_{51}$ & 7 & 70 \\
$\mathrm{Fe}_{58} \mathrm{Nb}_{42}$ & 6 & 45 & $\mathrm{Co}_{57} \mathrm{Nb}_{43}$ & 3 & 48 & $\mathrm{Ni}_{84} \mathrm{Nb}_{16}$ & 150 & 390 \\
$\mathrm{Fe}_{36} \mathrm{Nb}_{64}$ & 3 & 35 & $\mathrm{Co}_{40} \mathrm{Nb}_{60}$ & 9 & 78 & $\mathrm{Ni}_{60} \mathrm{Nb}_{40}$ & 100 & 95 \\
$\mathrm{Fe}_{92} \mathrm{Ta}_{8}$ & 200 & 190 & $\mathrm{Co}_{92} \mathrm{Ta}_{8}$ & 620 & 200 & $\mathrm{Ni}_{83} \mathrm{Ta}_{17}$ & 480 & 120 \\
$\mathrm{Fe}_{58} \mathrm{Ta}_{42}$ & 25 & $\sim 1$ & $\mathrm{Co}_{57} \mathrm{Ta}_{43}$ & 20 & 101 & $\mathrm{Ni}_{64} \mathrm{Ta}_{36}$ & 90 & 50 \\
$\mathrm{Fe}_{34} \mathrm{Ta}_{66}$ & $\sim 1$ & 85 & $\mathrm{Co}_{42} \mathrm{Ta}_{58}$ & 15 & 40 & $\mathrm{Ni}_{44} \mathrm{Cr}_{56}$ & 75 & 330 \\
$\mathrm{Fe}_{78} \mathrm{Cr}_{22}$ & 70 & 220 & $\mathrm{Co}_{59} \mathrm{Cr}_{41}$ & 66 & 45 & $\mathrm{Ni}_{64} \mathrm{Mo}_{36}$ & 420 & 380 \\
$\mathrm{Fe}_{90} \mathrm{Mo}_{10}$ & 160 & 150 & $\mathrm{Co}_{72} \mathrm{Mo}_{28}$ & 35 & 240 & $\mathrm{Ni}_{85} \mathrm{~W}_{15}$ & 280 & 265 \\
$\mathrm{Fe}_{75} \mathrm{Mo}_{25}$ & 150 & 135 & $\mathrm{Co}_{90} \mathrm{~W}_{10}$ & 170 & 220 & $\mathrm{Ni}_{80} \mathrm{~W}_{20}$ & 290 & 265 \\
$\mathrm{Fe}_{100-\mathrm{x}} \mathrm{W}_{\mathrm{x}}$ & $\mathrm{a}$ & $\mathrm{a}$ & $\mathrm{Co}_{79} \mathrm{~W}_{21}$ & 60 & 250 & & & \\
\hline
\end{tabular}

${ }^{a_{-x}}=2,5,10,15$ at.\%; very brittle diffusion layer. No further investigations were performed 

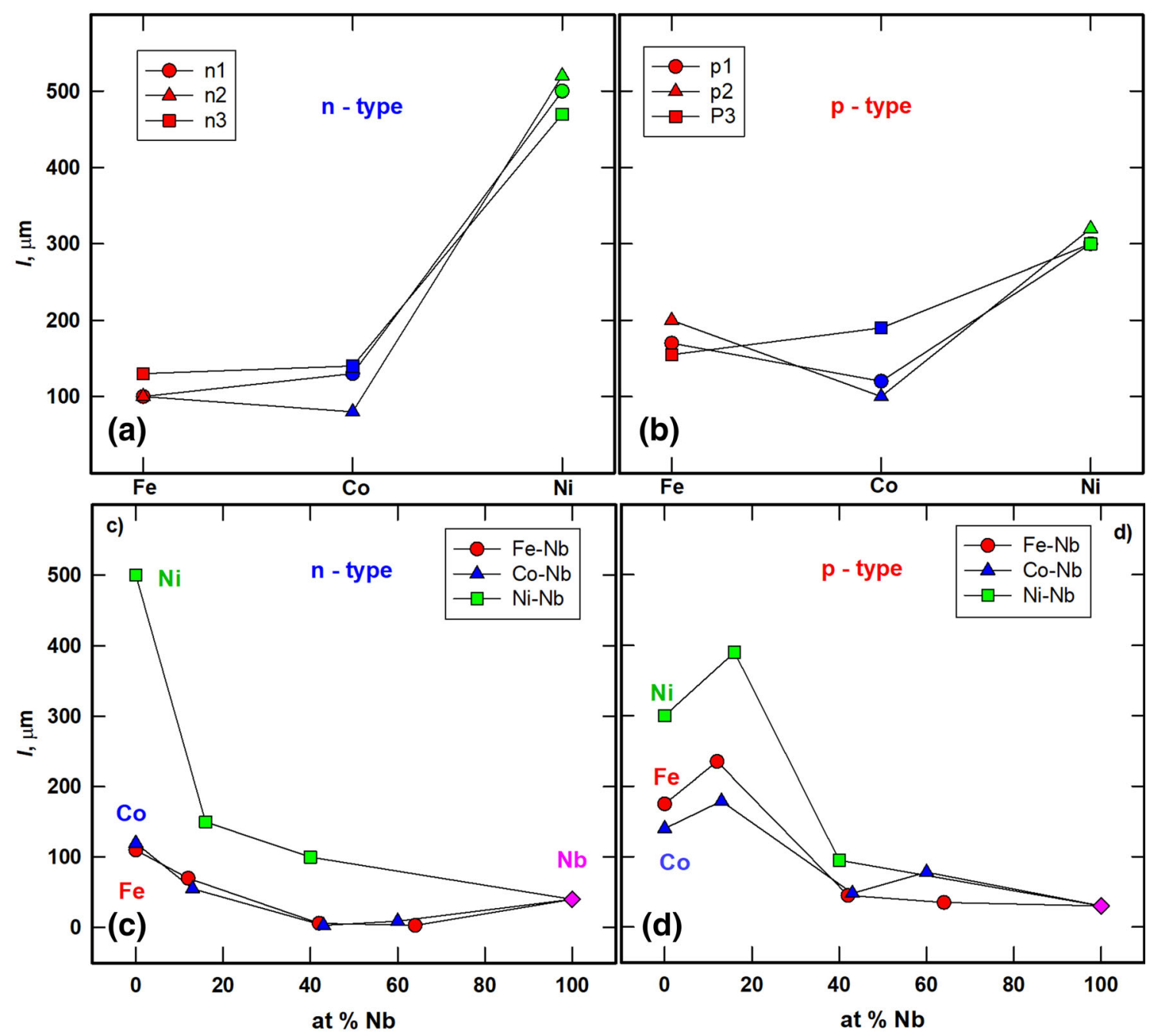

Fig. 6 Thickness of the diffusion layer forming during the interaction of skutterudites with $\mathrm{Fe}, \mathrm{Co}$ and $\mathrm{Ni}(\mathrm{a}, \mathrm{b})$ and binary (Fe,Co,Ni)-Nb (c, d) compositions

$\mathrm{NbNi}_{3}$ with $\mathrm{TiCu}_{3}$ structure forms in the $\mathrm{Nb}-\mathrm{Ni}$ system. The same structure types form also in binary systems with Ta and other elements, but their effect on the interaction with skutterudites differs (Fig. 7).

The constitution of the reaction zone (Figs S2-S3, Supplementary information) was in many cases much more complicated than in case of the interaction with pure elements (Fig. 3 and 4, and Table 2), and several unknown phases were detected and will be the subject of forthcoming investigations. Complete phase characterization will be published after a complete structural identification, however it became evident that the formation of particular phases in the diffusion zone were governed by the phase equilibria whilst the extensions of the diffusion zones depended on their crystal structure and the possibility to dissolve foreign atoms. The chemical stability of the contact (absence of interaction) was warranted under the condition that phases were in a thermodynamic equilibrium, and small extensions of their homogeneity regions of their phases indicated that they could act as efficient diffusion barriers.

These considerations are also helpful for the development of segmented TE legs. As example, the ternary systems (Ti, $\mathrm{V}, \mathrm{Zr}$ )-Co-Sb contain two "thermoelectric" phases: $\mathrm{CoSb}_{3}$ and $\mathrm{HH}-(\mathrm{Ti}, \mathrm{V}, \mathrm{Zr}) \mathrm{CoSb}$. According to the constitution of these ternary systems, ${ }^{[43-45]}$ these phases coexist in equilibrium (Fig. 5), providing a thermodynamically stable contact. In addition, $\mathrm{HH}$ phases are in equilibrium with metals or with M-Co intermetallics, which in the case of a good thermal and electrical conductivity may serve as chemically stable electrode materials, as the following examples show: the formation of $\mathrm{HH}$ was observed in the diffusion couple between n-type materials: (a) $\mathrm{TiCoSb}$ and $\mathrm{Ti}$ (in contact with skutterudite) and (b) $\mathrm{V}(\mathrm{CoFe}) \mathrm{Sb}$ and $\mathrm{Fe}_{70} \mathrm{~V}_{30}$ (in contact with the intermetallic phases). The interaction of $\mathrm{Fe}_{70} \mathrm{~V}_{30}$ with 
Fig. 7 Compositional dependences of thickness of the diffusion layers for $(\mathrm{Fe}, \mathrm{Co}, \mathrm{Ni})$ (Ti,V,Ta,Mo,W) binary alloys

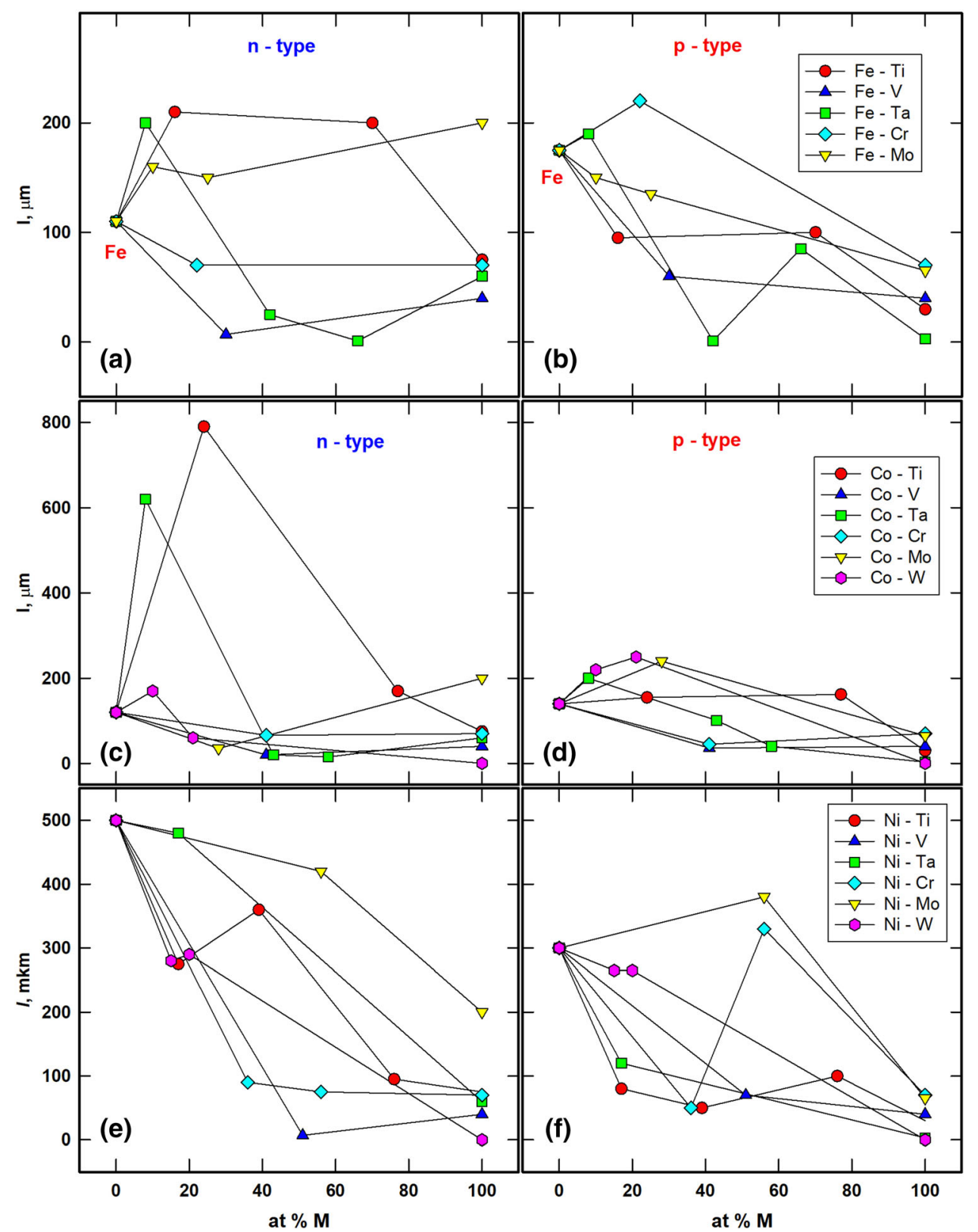

p-type material revealed the formation of $\mathrm{HH}-\mathrm{VFeSb}$ (in contact with the intermetallic phase). Furthermore, the reaction of $\mathrm{Fe}_{84} \mathrm{Ti}_{16}$ with both skutterudites results in the formation of a new off-stoichiometric compound, $\mathrm{TiFe}_{1.33} \mathrm{Sb}$, ${ }^{[49]}$ whilst off-stoichiometric $\mathrm{HH}-\mathrm{Nb}_{1-\mathrm{x}} \mathrm{CoSb}$ forms during the interaction of $\mathrm{Fe}-\mathrm{Nb}$ alloys with n-type skutterudites and it also coexists in equilibrium with $\mathrm{CoSb}_{3}$ (Fig. 5d) according to the calculated phase diagram $\mathrm{Nb}$ $\mathrm{Co}-\mathrm{Sb}$ at $0 \mathrm{~K}^{[46]}$

The same considerations are valid for other promising candidates for diffusion barrier-antimony rich binary $\mathrm{MSb}_{2}$, which form equilibria with $\mathrm{CoSb}_{3}$ (Fig. 5) and show only small solubility for the elements that are the main constituents of $\mathrm{p}$ - and n-skutterudites ( $\mathrm{Co}, \mathrm{Fe}$ and $\mathrm{Ni}$ ). It is important to note that equilibria, existing in this ternary system, are present also in higher order systems, and therefore this methodology may be used for the determination of a proper diffusion barrier in any Sb-based TE material.

Besides the chemical compatibility of the contacts and particularities of the crystal structure of the contacted materials, one has to consider the thermo-mechanical stability of the bonding (mechanical properties, thermal expansion coefficients, etc.), and the possibility to engineer these properties via substitution without changing the phase equilibria. 


\section{Conclusions}

Investigations of the interaction of antimony based skutterudites with pure metals and various binary compositions revealed two main chemical criteria for the development of a chemically stable and efficient diffusion barrier (or electrode) for the operation in contact with skutterudites at high temperatures. The material (a) has to be in thermodynamic equilibrium with the skutterudite, and (b) show a low solubility of elements that are constituents of electrode materials and skutterudites. The investigation revealed several materials, such as: pure metals, $\mathrm{Nb}, \mathrm{Ta}, \mathrm{W}$ and $\mathrm{Re}$, high antimonides of transitional elements of the IV and V groups and nitrides (TiN). Based on the experimental results obtained and the analysis of literature data on the atom site preference in the skutterudites, five groups of elements were defined according to their ability to interact with skutterudites. It was shown that the quality of the interfaces between phases in the diffusion zone may be adjusted by chemical substitution, and this provides a better thermo-mechanical stability of contacts in TE modules.

Acknowledgment Open access funding provided by University of Vienna. The authors thank the Austrian Research Promotion Agency (FFG) for support via Project 818077 "KON-TEG" (01.08.2008-31.07.2010).

Open Access This article is licensed under a Creative Commons Attribution 4.0 International License, which permits use, sharing, adaptation, distribution and reproduction in any medium or format, as long as you give appropriate credit to the original author(s) and the source, provide a link to the Creative Commons licence, and indicate if changes were made. The images or other third party material in this article are included in the article's Creative Commons licence, unless indicated otherwise in a credit line to the material. If material is not included in the article's Creative Commons licence and your intended use is not permitted by statutory regulation or exceeds the permitted use, you will need to obtain permission directly from the copyright holder. To view a copy of this licence, visit http://creativecommons. org/licenses/by/4.0/.

\section{References}

1. G. Rogl, A. Grytsiv, P. Rogl, E. Royanian, E. Bauer, J. Horky, D. Setman, E. Schafler, and M. Zehetbauer, Dependence of Thermoelectric Behaviour on Severe Plastic Deformation Parameters. A Case Study on p-Type Skutterudite $\mathrm{DD}_{0.60} \mathrm{Fe}_{3} \mathrm{CoSb}_{12}$, Acta Mater., 2013, 61, p 6778-6789

2. G. Rogl, A. Grytsiv, P. Rogl, N. Peranio, E. Bauer, M. Zehetbauer, and $\mathrm{O}$. Eibl, N-Type Skutterudites $(\mathrm{R}, \mathrm{Ba}, \mathrm{Yb})_{\mathrm{y}} \mathrm{Co}_{4} \mathrm{Sb}_{12}$ $(\mathrm{R}=\mathrm{Sr}, \mathrm{La}, \mathrm{Mm}, \mathrm{DD}, \mathrm{SrMm}, \mathrm{SrDD})$ Approaching $\mathrm{ZT} \sim 2.0$, Acta Mater., 2014, 63, p 30-43

3. G. Rogl, A. Grytsiv, E. Bauer, and P. Rogl, Thermoelectric SbBased Skutterudites for Medium Temperatures, Chapter 5, Advanced Thermoelectrics. Materials Contacts, Devices, and Systems, Z. Ren, Y. Lan, and Q. Zhang, Ed., CRC Press, Boca Raton, 2017, p 193-229
4. L. Zhang, G. Rogl, A. Grytsiv, S. Puchegger, J. Koppensteiner, F. Spieckermann, H. Kabelka, M. Reinecker, P. Rogl, W. Schranz, M. Zehetbauer, and M.A. Carpenter, Mechanical Properties of Filled Antimonide Skutterudites, Mater. Sci. Eng. B Solid-State Mater. Adv. Technol., 2010, 170, p 26-31

5. G. Rogl and P. Rogl, Mechanical Properties of Skutterudites, Sci. Adv. Mater., 2011, 3, p 517-538

6. G. Rogl, L. Zhang, P. Rogl, A. Grytsiv, M. Falmbigl, D. Rajs, M. Kriegisch, H. Mueller, E. Bauer, J. Koppensteiner, W. Schranz, M. Zehetbauer, Z. Henkie, and M.B. Maple, Thermal Expansion of Skutterudites, J. Appl. Phys., 2010, 107, p 043507

7. A. Rao, G. Bosak, B. Joshi, J. Keane, L. Nally, A. Peng, S. Perera, A. Waring, and B. Poudel, A TiAlCu Metallization for "n" Type $\mathrm{CoSb}_{\mathrm{x}}$ Skutterudites with Improved Performance for High-Temperature Energy Harvesting Applications, J. Electron. Mater., 2017, 46, p 2419-2431

8. J.Q. Guo, H.Y. Geng, T. Ochi, S. Suzuki, M. Kikuchi, Y. Yamaguchi, and S. Ito, Development of Skutterudite Thermoelectric Materials and Modules, J. Electron. Mater., 2012, 41, p 10361042

9. K.T. Wojciechowski, R. Zybala, and R. Mania, High Temperature $\mathrm{CoSb}_{3}-\mathrm{Cu}$ Junctions, Microelectron. Reliab., 2011, 51, p 1198-1202

10. A. Muto, J. Yang, B. Poudel, Z. Ren, and G. Chen, Skutterudite Unicouple Characterization for Energy Harvesting Applications, Adv. Energy Mater., 2013, 3, p 245-251

11. H. Hazama, Y. Masuoka, A. Suzumura, M. Matsubara, S. Tajima, and R. Asahi, Cylindrical Thermoelectric Generator with Water Heating System for High Solar Energy Conversion Efficiency, Appl. Energy, 2018, 226, p 381-388

12. J. Peng, T. Zhang, J. Yang, and K. Cui, Preparation and Interface Analysis of the Segmented $\mathrm{CoSb}_{3} / \mathrm{Bi}_{2} \mathrm{Te}_{3}$, Thermoelectric Materials, Mater. Sci. Forum, 2003, 423, p 373-376

13. L. Boulat, R. Viennois, D. Ravot, and N. Fréty, Diffusion Barriers for $\mathrm{CeFe}_{4} \mathrm{Sb}_{12} / \mathrm{Cu}$ Thermoelectric Devices, Mater. Res. Soc. Symp. Proc., 2013, 1490, p 197-202

14. L. Boulat, R. Viennois, E. Oliviero, M. Dadras, and N. Frety, Study of TaN and TaN-Ta-TaN Thin Films as Diffusion Barriers in $\mathrm{CeFe}_{4} \mathrm{Sb}_{12}$ Skutterudite, J. Appl. Phys., 2019, 126, p 125306

15. B. Song, S. Lee, S. Cho, M.-J. Song, S.-M. Choi, W.-S. Seo, Y. Yoon, and W. Lee, The Effects of Diffusion Barrier Layers on the Microstructural and Electrical Properties in $\mathrm{CoSb}_{3}$ Thermoelectric Modules, J Alloys Compd., 2014, 617, p 160-162

16. H.H. Saber and M.S. El-Genk, Performance of a SkutteruditeBased Segmented Unicouple with a Metallic Coating Near Hot Junction, in Space Technology and Applications International Forum-Staifm, AIP Conference Proceedings (2005), pp. 572-583

17. D. Zhao, X. Li, L. He, W. Jiang, and L. Chen, Interfacial Evolution Behavior and Reliability Evaluation of $\mathrm{CoSb}_{3} / \mathrm{Ti} / \mathrm{Mo}-\mathrm{Cu}$ Thermoelectric Joints During Accelerated Thermal Aging, $J$. Alloys Compd., 2009, 477, p 425-431

18. R. Zybala, K. Wojciechowski, M. Schmidt, and R. Mania, Junctions and Diffusion Barriers for High Temperature Thermoelectric Modules, Ceram. Mater., 2010, 62, p 481-485

19. W.-A. Chen, S.-W. Chen, S.-M. Tseng, H.-W. Hsiao, Y.-Y. Chen, G.J. Snyder, and Y. Tang, Interfacial Reactions in $\mathrm{Ni} / \mathrm{CoSb}_{3}$ Couples at 450 C, J. Alloys Compd., 2015, 632, p 500-504

20. T. Caillat, J.-P. Fleurial, G.J. Snyder, and A. Borshchevsky, Development of High Efficiency Segmented Thermoelectric Unicouples, in International Conference on Thermoelectrics. ICT Proceedings, 2001 (Beijing), IEEE (2001), pp. 282-285

21. J.F. Fan, L.D. Chen, S.Q. Bai, and X. Shi, Joining of Mo to $\mathrm{CoSb}_{3}$ by Spark Plasma Sintering by Inserting a Ti Interlayer, Mater. Lett., 2004, 58, p 3876-3878 
22. D. Zhao, L. Xiaoya, L. He, W. Jiang, and L. Chen, High Temperature Reliability Evaluation of $\mathrm{CoSb}_{3}$ /Electrode Thermoelectric Joints, Intermetallics, 2009, 17, p 136-141

23. L. Zhang, A. Grytsiv, P. Rogl, E. Bauer, and M. Zehetbauer, High Thermoelectric Performance of Triple-Filled n-Type Skutterudites $(\mathrm{Sr}, \mathrm{Ba}, \mathrm{Yb})_{\mathrm{y}} \mathrm{Co}_{4} \mathrm{Sb}_{12}$, J. Phys. D Appl. Phys., 2009, 42, p 225405-1-225405-9

24. D. Zhao, H. Geng, and L. Chen, Microstructure Contact Studies for Skutterudite Thermoelectric Devices, Int. J. Appl. Ceram. Technol., 2012, 9, p 733-741

25. M. Gu, X. Xia, X. Huang, S. Bai, X. Li, and L. Chen, Study on the Interfacial Stability of p-Type Ti/Ce $\mathrm{Fe}_{\mathrm{x}} \mathrm{Co}_{4-\mathrm{x}} \mathrm{Sb}_{12}$ Thermoelectric Joints at High Temperature, J. Alloys Compd., 2016, 671, p 238-244

26. J. Prado-Gonjal, M. Phillips, P. Vaqueiro, G. Min, and A.V. Powell, Skutterudite Thermoelectric Modules with High VolumePower-Density, Scalability and Reproducibility, ACS Appl. Energy Mater., 2018, 1, p 6609-6618

27. Y. Yan, H. Ke, J. Yang, C. Uher, and X. Tang, Fabrication and Thermoelectric Properties of n-Type $\mathrm{CoSb}_{2.85} \mathrm{Te}_{0.15}$ Using Selective Laser Melting, ACS Appl. Mater. Interfaces, 2018, 10, p 13669-13674

28. K. Kaszyca, M. Schmidt, M. Chmielewski, K. Pietrzak, and R. Zybala, Joining of Thermoelectric Material with Metallic Electrode Using Spark Plasma Sintering (SPS) Technique, Mater. Today Proc., 2018, 5(4), p 10277-10282

29. K.H. Bae, S.-M. Choi, K.-H. Kim, H.-S. Choi, W.-S. Seo, I.-H. Kim, S. Lee, and H.J. Hwang, Power-Generation Characteristics After Vibration and Thermal Stresses of Thermoelectric Unicouples with $\mathrm{CoSb}_{3} / \mathrm{Ti} / \mathrm{Mo}(\mathrm{Cu})$ Interfaces, J. Electron. Mater., 2015, 44, p 2124-2131

30. J.R. Salvador, J.Y. Cho, Z. Ye, J.E. Moczygemba, A.J. Thompson, J.W. Sharp, J.D. Koenig, R. Maloney, T. Thompson, J. Sakamoto, H. Wang, and A.A. Wereszczak, Conversion Efficiency of Skutterudite-Based Thermoelectric Modules, Phys. Chem. Chem. Phys., 2014, 16, p 12510-12520

31. M. Gu, S. Bai, X. Xia, X. Huang, X. Li, X. Shi, and L. Chen, Study on the High Temperature Interfacial Stability of Ti/Mo/ $\mathrm{Yb}_{0.3} \mathrm{Co}_{4} \mathrm{Sb}_{12}$ Thermoelectric Joints, Appl. Sci., 2017, 7, p 7090952

32. J. Garcìa-Cañadas, A. Powell, A. Kaltzoglou, P. Vaqueiro, and G. Min, Fabrication and Evaluation of a Skutterudite-Based Thermoelectric Module for High-Temperature Applications, J. Electron. Mater., 2013, 42, p 1369-1374

33. L. Shi, X. Huang, M. Gu, and L. Chen, Interfacial Structure and Stability in Ni/SKD/Ti/Ni Skutterudite Thermoelements, Surf. Coat. Technol., 2016, 285, p 312-317

34. S. Katsuyama, W. Yamakawa, Y. Matsumura, and R. Funahashi, Fabrication of Thermoelectric Module Consisting of Rare-EarthFilled Skutterudite Compounds and Evaluation of Its Power Generation Performance in Air, J. Electron. Mater., 2019, 48, p 5257-5263

35. X.C. Fan, M. Gu, X. Shi, L.D. Chen, S.Q. Bai, and R. Nunna, Fabrication and Reliability Evaluation of $\mathrm{Yb}_{0.3} \mathrm{Co}_{4} \mathrm{Sb}_{12} / \mathrm{Mo}-\mathrm{Ti} /$ Mo-Cu/Ni Thermoelectric Joints, Ceram. Int., 2015, 1, p 75907595

36. M.S. Kim, J.P. Ahn, K.H. Kim, K.J. Kim, J.S. Park, W.S. Seo, and H.S. Kim, Joining Properties of $\mathrm{CoSb}_{3} / \mathrm{Al} / \mathrm{Ti} / \mathrm{CuMo}$ by Spark Plasma Sintering Process, J. Korean Ceram. Soc., 2014, 51, p 549-553
37. M. Gu, X. Xia, X. Li, X. Huang, and L. Chen, Microstructural Evolution of the Interfacial Layer in the $\mathrm{Ti}-\mathrm{Al} / \mathrm{Yb}_{0.6} \mathrm{Co}_{4} \mathrm{Sb}_{12}$ Thermoelectric Joints at High Temperature, J. Alloys Compd., 2014, 610, p 665-670

38. Q. Zhang, J. Liao, Y. Tang, M. Gu, C. Ming, P. Qiu, S. Bai, X. Shi, C. Uher, and L. Chen, Realizing a Thermoelectric Conversion Efficiency of $12 \%$ in Bismuth Telluride/Skutterudite Segmented Modules Through Full-Parameter Optimization and Energy-Loss Minimized Integration, Energy Environ. Sci., 2017, 10, p 956-963

39. Q.-H. Zhang, J.-C. Liao, Y.-S. Tang, M. Gu, R.-H. Liu, S.-Q. Bai, and L.-D. Chen, Interface Stability of Skutterudite Thermoelectric Materials $/ \mathrm{Ti}_{88} \mathrm{Al}_{12}$, Wuji Cailiao Xuebao, 2018, 33, p 889894

40. S.H. Park, Y. Jin, J. Cha, K. Hong, Y. Kim, H. Yoon, C.-Y. Yoo, and I. Chung, High-Power-Density Skutterudite-Based Thermoelectric Modules with Ultralow Contact Resistivity Using Fe-Ni Metallization Layers, ACS Appl. Energy Mater., 2018, 1, p 16031611

41. K. Placha, R.S. Tuley, M. Salvo, V. Casalegno, and K. Simpson, Solid-Liquid Interdiffusion (SLID) Bonding of p-Type Skutterudite Thermoelectric Material Using Al-Ni Interlayers, Materials, 2018, 11, p 2483

42. A. Tavassoli, A. Grytsiv, F. Failamani, G. Rogl, S. Puchegger, H. Müller, P. Broz, F. Zelenka, D. Maccio, A. Saccone, G. Giester, E. Bauer, M. Zehetbauer, and P. Rogl, Constitution of the Binary M-Sb Systems ( $\mathrm{M}=\mathrm{Ti}, \mathrm{Zr}, \mathrm{Hf})$ and Physical Properties of $\mathrm{MSb}_{2}$, Intermet, 2018, 94, p 119-132

43. Y.V. Stadnyk, L.P. Romaka, A.M. Horyn, A.V. Tkachuk, Y.K. Gorelenko, and P. Rogl, Isothermal Sections of the Ti-Co-Sn and Ti-Co-Sb Systems, Alloys Compd., 2005, 387, p 251-255

44. L. Romaka, V.V. Romaka, N. Melnychenko, Y. Stadnyk, L. Bohun, and A. Horyn, Experimental and DFT Study of the V-CoSb Ternary System, J. Alloys Compd., 2018, 739, p 771-779

45. V.V. Romaka, L. Romaka, P. Rogl, Y. Stadnyk, N. Melnychenko, R. Korzh, Z. Duriagina, and A. Horyn, Peculiarities of Thermoelectric Half-Heusler Phase Formation in $\mathrm{Zr}-\mathrm{Co}-\mathrm{Sb}$ Ternary System, J. Alloys Compd., 2014, 585, p 448-454

46. W.G. Zeier, S. Anand, L. Huang, R. He, H. Zhang, Z. Ren, C. Wolverton, and G.J. Snyder, Using the 18-Electron Rule To Understand the Nominal 19-Electron Half-Heusler NbCoSb with Nb Vacancies, Chem. Mater., 2017, 29, p 1210-1217

47. F. Failamani, P. Broz, D. Maccio, S. Puchegger, H. Müller, L. Salamakha, H. Michor, A. Grytsiv, A. Saccone, E. Bauer, G. Giester, and P. Rogl, Constitution of the Systems $\{\mathrm{V}, \mathrm{Nb}, \mathrm{Ta}\}-\mathrm{Sb}$ and Physical Properties of Di-Antimonides $\{\mathrm{V}, \mathrm{Nb}, \mathrm{Ta}\} \mathrm{Sb}_{2}, \mathrm{In}$ termetallics, 2015, 65, p 94-110

48. F. Failamani, A. Grytsiv, G. Giester, G. Polt, P. Heinrich, H. Michor, E. Bauer, M. Zehetbauer, and P. Rogl, Ba $\{\text { V, Nb }\}_{12}$ $\mathrm{Sb}_{19+\mathrm{x}}$, Novel Variants of the $\mathrm{Ba}_{5} \mathrm{Ti}_{12} \mathrm{Sb}_{19+\mathrm{x}}$-type: Crystal Structure and Physical Properties, Phys. Chem. Chem. Phys., 2015, 17(37), p 24248-24261

49. A. Tavassoli, A. Grytsiv, G. Rogl, V. Romaka, H. Michor, M. Reissner, E. Bauer, M. Zehetbauer, and P. Rogl, The Half Heusler System $\mathrm{Ti}_{1+x} \mathrm{Fe}_{1.33-\mathrm{x}} \mathrm{Sb}$-TiCoSb with $\mathrm{Sb} / \mathrm{Sn}$ Substitution, Phase Relations, Crystal Structures and Thermoelectric Properties, Dalton Trans., 2018, 47, p 879-897

Publisher's Note Springer Nature remains neutral with regard to jurisdictional claims in published maps and institutional affiliations. 